JEKPEND Jurnal Ekonomi dan Pendidikan

Volume 1 Nomor 1 Januari 2018. Hal. 34-44

p-ISSN: 2614-2139; e-ISSN: 2614-1973,

Homepage: http://ojs.unm.ac.id/JEKPEND

\title{
PENERAPAN MODEL PEMBELAJARAN KOOPERATIF TIPE SNOWBALL THROWING UNTUK MENINGKATKAN HASIL BELAJAR IPS SISWA KELAS VIII.B SMP NEGERI 33 MAKASSAR
}

\author{
Hj. Rosmawati \\ Guru SMP Negeri 33 Makassar \\ Email: hjrsmp33@gmail.com
}

\begin{abstract}
This study aims to improve the learning outcomes of IPS through the implementation of cooperative learning model of snowball throwing type in students of class VIII.B SMP Negeri 33 Makassar. The type of research is action research. The focus of research is the type of cooperative learning model of snowball throwing and IPS learning outcomes. Data were collected using observation, test, and documentation, while the research data was analyzed descriptively. The results of the study that IPS learning outcomes can be increased through the application of cooperative learning model of snowball throwing type. Cycle I, IPS learning outcomes including good category but not yet reached the defined learning completeness criteria, then cycle II is in very good category and has reached defined learning completeness criteria. The increase of learning result of IPS through the implementation of cooperative learning model of snowball throwing type is supported by the increase of students' learning activity, such as: student activeness and group leader listening teacher explanation related to material / theme, making questions, answer written questions in ball-shaped paper, IPS lessons on the theme of location excellence and the life of Indonesian society.
\end{abstract}

Keywords: Cooperative Learning Model Type Snowball Throwing, Learning Outcomes, Science Social Knowledge (IPS).

\begin{abstract}
Abstrak: Penelitian ini bertujuan meningkatkan hasil belajar IPS melalui penerapan model pembelajaran kooperatif tipe snowball throwing pada siswa kelas VIII.B SMP Negeri 33 Makassar. Jenis penelitian adalah penelitian tindakan. Fokus penelitian yaitu model pembelajaran kooperatif tipe snowball throwing dan hasil belajar IPS. Data dikumpulkan menggunakan observasi, tes, dan dokumentasi, sedangkan data penelitian dianalisis secara deskriptif. Hasil penelitian yaitu hasil belajar IPS dapat meningkat melalui penerapan model pembelajaran kooperatif tipe snowball throwing. Siklus I, hasil belajar IPS termasuk kategori baik tetapi belum mencapai kriteria ketuntasan belajar yang ditetapkan, kemudian siklus II berada pada kategori baik sekali dan telah mencapai kriteria ketuntasan belajar yang ditetapkan. Terjadinya peningkatan hasil belajar IPS melalui penerapan model pembelajaran kooperatif tipe snowball throwing didukung peningkatan aktivitas belajar siswa, berupa: keaktifan siswa dan ketua kelompok menyimak penjelasan guru berkaitan dengan materi/tema, membuat pertanyaan, menjawab pertanyaan tertulis dalam kertas yang berbentuk bola, dan menyimpulkan materi pelajaran IPS tema keunggulan lokasi dan kehidupan masyarakat Indonesia.
\end{abstract}

Kata Kunci: Model Pembelajaran Kooperatif Tipe Snowball Throwing, Hasil Belajar, Ilmu Pengetahuan Sosial (IPS).

\section{PENDAHULUAN}

Pendidikan sekolah merupakan lembaga pembinaan sumber daya manusia Indonesia secara berjenjang atau berkelanjutan, berupa

pengembangan kemampuan siswa aspek kognitif, afektif maupun psikomotor. Hal ini 
sejalan dengan fungsi dan tujuan Undang-Undang Republik Indonesia Nomor 20 tahun 2003 tentang Sistem Pendidikan Nasional, Pasal 3 (2003:7), yaitu:

Pendidikan nasional berfungsi untuk mengembangkan kemampuan dan membentuk watak serta peradaban bangsa yang bermartabat dalam rangka mencerdaskan kehidupan bangsa, bertujuan untuk berkembangnya potensi peserta didik agar menjadi manusia yang beriman dan bertaqwa kepada Tuhan Yang Maha Esa, berakhlak mulia, sehat, berilmu, cakap, kreatif, mandiri, dan menjadi warga negara yang demokratis serta bertanggung jawab.

Salah satu upaya pencapaian tuj uan pendidikan tersebut adalah melalui proses pembelajaran Ilmu Pengetahuan Sosial (IPS). Proses pembelajaran IPS di SMP berorientasi pada pengembangan kemampuan belajar, di antaranya pengembangan kemampuan mendalami berbagai peristiwa sosial, dan sejarah yang menjadi bahasan dalam pelajaran IPS. Agar materi pelajaran IPS lebih mudah dipahami oleh siswa, guru harus kreatif memperhatikan komponen yang dapat mempengaruhi kualitas pembelajaran, di antaranya penerapan model pembelajaran yang relevan dengan materi, tujuan pembelajaran, dan karakteristik siswa sehingga siswa dapat mengikuti pelajaran IPS dengan baik dalam mendukung peningkatan hasil belajarnya.

Proses pembelajaran IPS seharusnya lebih mengedepankan keaktifan siswa dalam belajar. Akan tetapi suatu fenomena dalam pembelajaran yaitu guru lebih cenderung menguasai pembelajaran mulai dari awal hingga akhir pembelajaran, sementara siswa hanya pasif dengan cara mencatat atau mendengar penjelasan guru. Akibatnya, siswa dapat mengalami perasaan bosan mengikuti pelajaran, dan perasaan mengantuk saat belajar. Di samping itu, fenomena yang sering terjadi pada diri siswa dalam pelajaran IPS, yaitu mudah lupa materi meskipun baru diajarkan oleh guru. Hal ini mengakibatkan materi selanjutnya sulit dipahami karena materi pelajaran IPS saling berkesinambungan, dan adanya siswa kurang mampu melibatkan diri secara aktif dalam pembelajaran sehingga mempengaruhi rendahnya hasil belajar siswa, karena materi yang diajarkan oleh guru kadang-kadang kurang dipahami oleh siswa secara maksimal sehingga mempengaruhi kemampuannya menyelesaikan soal-soal IPS pada saat evaluasi hasil belajar. pendidikan nasional yang tercantum dalam Berdasarkan observasi awal pembelajaran IPS di kelas VIII.B SMP Negeri 33 Makassar, nilai rata-rata hasil belajar IPS siswa sebagian masih lebih rendah dari standar KKM 80. Rendahnya hasil belajar IPS siswa dibandingkan standar KKM disebabkan oleh berbagai faktor, di antaranya: rendahnya partisipasi dalam belajar IPS, dan jarang mengerjakan tugas. Demikian pula kurang mengarahkan siswa untuk aktif belajar sehingga mempengaruhi hasil belajar.

Proses pembelajaran IPS yang diinginkan adalah model pembelajaran yang dapat membuat siswa terasa mudah dan menyenangkan, dan lebih aktif dalam mengikuti pelajaran IPS sehingga penguasaan materi dapat lebih maksimal. Salah satu model pembelajaran yang dapat diterapkan guru dalam pelajaran IPS adalah pembelajaran kooperatif. Pembelajaran kooperatif merupakan model pembelajaran yang menekankan pada kerjasama dalam kelompok, sebagaimana dikemukakan oleh Isjoni (2010:5) bahwa "model pembelajaran kooperatif, siswa diberi kesempatan berkomunikasi dan berinteraksi dengan temannya untuk mencapai tujuan pembelajaran, sementara guru sebagai motivator dan fasilitator aktivitas siswa". Pendapat ini menekankan pembelajaran kooperatif kepada kegiatan pembelajaran secara kelompok melalui motivator dan fasilitator guru.

Penerapan pembelajaran kooperatif dipandang sebagai salah satu solusi dalam meningkatkan kualitas pembelajaran, khususnya dalam meningkatkan keaktifan siswa mengikuti pelajaran, di antaranya pembelajaran kooperatif tipe snowball throwing. Proses pembelajaran kooperatif tipe snowball throwing diawali dengan penyajian materi pelajaran, kemudian pembentukan kelompok, kemudian setiap ketua kelompok dipanggil untuk diberikan penjelasan tentang materi, dan setiap ketua kelompok kembali ke kelompoknya dan menjelaskan materi yang disampaikan oleh guru. Setiap siswa diberikan satu lembar kerja untuk menuliskan satu pertanyaan berkaitan dengan materi yang sudah dijelaskan oleh ketua kelompok. Kertas berisi pertanyaan dibuat seperti bola dan dilempar dari satu siswa ke siswa yang lain sekitar 15 menit. Setelah siswa dapat satu bola (satu pertanyaan), maka siswa diberi kesempatan menjawab pertanyaan secara tertulis dalam kertas berbentuk bola tersebut secara bergantian, kemudian penilaian dan penutup. 
Melalui penggunakan model pembelajaran snowball throwing, siswa diharapkan lebih aktif dalam belajar dan termotivasi membuat pertanyaan dan menjawab pertanyaan berkaitan dengan materi yang diajarkan oleh guru sehingga diharapkan dapat meningkatkan kemampuan belajar dan hasil belajarnya. Melalui penerapan model pembelajaran snowball throwing secara konsisten, maka siswa diharapkan dapat lebih aktif belajar dan lebih menguasai materi pelajaran. Kondisi tersebut diharapkan dapat berimplikasi terhadap peningkatan hasil belajar siswa.

berkaitan dengan hal itu, maka penulis terinspirasi mengkaji secara empiric melalui penelitian tindakan kelas dengan menerapkan model pembelajaran snowball throwing dengan judul: Penerapan model pembelajaran kooperatif tipe snowball throwing untuk meningkatkan hasil belajar IPS siswa kelas VIII.B SMP Negeri 33 Makassar

\section{DAFTAR PUSTAKA}

Salah satu model pembelajaran yang dapat diterapkan di sekolah adalah pembelajaran kooperatif. Pembelajaran kooperatif adalah model pembelajaran yang berorientasi pada kegiatan kerjasama antara siswa dalam bentuk kelompok, sebagaimana dikemukakan oleh Sanjaya (2006:33) bahwa "model pembelajaran kelompok adalah rangkaian kegiatan belajar yang dilakukan oleh siswa dalam kelompokkelompok tertentu untuk mencapai tujuan yang telah dirumuskan". Anita (2007:2) menyatakan bahwa "model pembelajaran kooperatif merupakan model pembelajaran yang mengutamakan adanya kelompok-kelompok serta di dalamnya menekankan kerjasama". Slavin (Isjoni, 2010:12) mengemukakan "pembelajaran kooperatif adalah suatu model pembelajaran di mana siswa belajar dalam kelompok kecil secara kolaboratif yang anggotanya 4-6 orang dengan struktur kelompok heterogen". Berdasarkan pendapat tersebut, maka dapat disimpulkan pembelajaran kooperatif merupakan model pembelajaran yang mengandung unsur kerjasama antara siswa dalam kelas dalam melakukan kerja kelompok, sehingga penekanan model ini adalah mengaktifkan siswa dalam pembelajaran melalui kerjasama antar siswa dalam kelompok.

Salah satu metode pembelajaran kooperatif adalah snowball throwing. Tipe snowball throwing merupakan suatu tipe pembelajaran yang menekankan kepada keaktifan siswa dalam belajar kelompok dengan mengunakan pertanyaan-pertanyaan secara tertulis pada secarik kertas yang dibuat seperti bola dan dilempar sehingga semua siswa mendapatkan pertanyaan dari temannya. Model ini memungkinkan siswa dapat lebih aktif dan kreatif membuat pertanyaan sekaligus menjawab pertanyaan yang berasal dari temannya. (Suprijono, 2010).

Menurut Suprijono (2010:128), langkahlangkah pembelajaran kooperatif tipe snowball throwing, yaitu:

a. Guru menyampaikan materi yang akan disajikan.

b. Guru membentuk kelompok dan memanggil masing-masing ketua kelompok untuk memberikan penjelasan tentang materi.

c. Masing-masing ketua kelompok kembali ke kelompoknya masing-masing, kemudian menjelaskan materi yang disampaikan oleh guru kepada temannya.

d. Kemudian masing-masing siswa diberikan satu lembar kertas kerja, untuk menuliskan satu pertanyaan apa saja yang menyangkut materi yang sudah dijelaskan oleh ketua kelompok.

e. Kemudian kertas yang berisi pertanyaan tersebut dibuat seperti bola dan dilempar dari satu siswa ke siswa yang lain sekitar 15 menit.

f. Setelah siswa dapat satu bola/satu pertanyaan diberikan kesempatan kepada siswa untuk menjawab pertanyaan yang tertulis dalam kertas berbentuk bola tersebut secara bergantian.

g. Evaluasi dan penutup

Berdasarkan pendapat di atas, maka langkah-langkah pembelajaran snowball throwing dalam pembelajaran IPS dipandang sebagai salah satu model pembelajaran yang mengedepankan keaktifan siswa dalam belajar, baik dalam membuat pertanyaan maupun menjawab pertanyaan. Penerapan model pembelajaran snowball throwing yang diawali dengan penyampaian materi pelajaran oleh guru dan pembentukan kelompok, kemudian setiap ketua kelompok dipanggil untuk diberi penjelasan tentang materi, dan masing-masing ketua kelompok kembali ke kelompoknya dan menjelaskan materi yang disampaikan oleh guru.

Setiap siswa diberikan satu lembar kertas kerja untuk menuliskan satu pertanyaan berkaitan dengan materi yang sudah dijelaskan oleh ketua kelompok. Kertas berisi pertanyaan 
dibuat seperti bola dan dilempar dari satu siswa ke siswa yang lain. Setelah siswa dapat satu bola (satu pertanyaan), maka siswa diberi kesempatan menjawab pertanyaan dalam kertas secara bergantian, kemudian penilaian dan penutup. Kegiatan penilaian dalam model ini dapat dilakukan setelah pembelajaran selesai. Model pembelajaran snowball throwing diharapkan siswa lebih aktif dan termotivasi membuat pertanyaan sekaligus menjawab pertanyaan sehingga dapat meningkatkan hasil belajarnya.

Hasil belajar siswa dapat dipengaruhi oleh berbagai faktor, baik berasal dari diri maupun dari luar diri siswa. Hasil belajar pada hakikatnya merupakan hasil interaksi antara berbagai faktor tersebut. Oleh karena itu, pengenalan guru terhadap faktor-faktor yang mempengaruhi hasil belajar siswa penting sekali dalam meningkatkan kualitas proses belajar dan hasil belajar siswa.

Purwanto (2007:102) meng emukakan faktor-faktor yang mempengaruhi hasil belajar yaitu:

a. Faktor yang ada pada diri organisme itu sendiri yang disebut faktor individual (kematangan/pertumbuhan, kecerdasan, latihan, motivasi, dan faktor pribadi).

b. Faktor yang ada di luar individu yang disebut faktor sosial (keluarga/keadaan rumah tangga, guru dan cara mengajarnya, alat-alat yang diperlukan dalam belajar mengajar, lingkungan dan kesempatan yang tersedia, dan motivasi sosial.

Lebih jelasnya mengenai faktor-faktor yang mempengaruhi hasil belajar siswa digambarkan oleh Purwanto sebagai berikut:

Gambar 1. Faktor-faktor yang mempengaruhi hasil belajar (Purwanto, 2007:106)

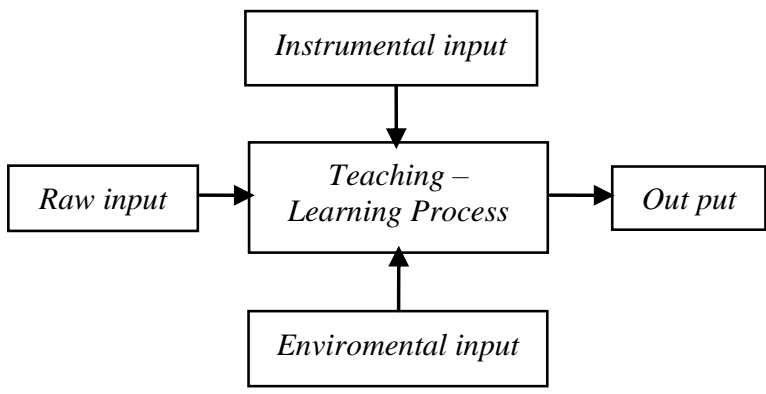
berikut:

Gambar tersebut dijelaskan sebagai

a. Raw input merupakan masukan mentah dalam pembelajaran terhadap siswa, berupa bahan pengalaman belajar tertentu dalam proses belajar mengajar. b. Teaching learning process merupakan proses belajar mengajar yang berlangsung yang dilakukan oleh guru (pendidik dan pengajar) dengan mengajarkan materi pelajaran tertentu. Dalam proses pembelajaran, ikut berpartisIPSsi sejumlah faktor lingkungan yang merupakan masukan dari lingkungan (enviromental input) dan sejumlah faktor instrumental (instrumental input) yang dengan sengaja dirancang guna menunjang tercapainya keluaran atau kemampuan belajar siswa.

c. Out put merupakan hasil dari proses pembelajaran, berupa pengetahuan, sikap, dan keterampilan siswa.

Pembelajaran kooperatif tipe snowball throwing dalam pembelajaran IPS memungkinkan siswa bekerjasama membahas materi. Setiap anggota kelompok harus aktif dalam mengerjakan tugas-tugas secara kelompok agar memiliki kesamaan pemahaman dan tingkat penguasaan materi pelajaran IPS yang maksimal sehingga mempengaruhi tingginya hasil belajar siswa di sekolah. Jika ada anggota kelompok kurang aktif, maka menjadi kewajiban anggota yang lainnya untuk memberikan dorongan kepada temannya agar termotivasi dan aktif dalam belajar secara kelompok.

\section{METODE PENELITIAN}

A. Jenis Penelitian

Jenis penelitian adalah penelitian tindakan kelas (classroom action research). Menurut Arikunto (2012: 3) bahwa "penelitian tindakan adalah suatu pencermatan terhadap kegiatan belajar berupa sebuah tindakan, yang sengaja dimunculkan dan terjadi dalam sebuah kelas secara bersama". Hal ini berarti penelitian tindakan kelas merupakan penelitian dalam bentuk tindakan yang dilakukan di kelas dalam bentuk proses pembelajaran. Penelitian ini mengkaji peningkatan hasil belajar IPS melalui penerapan model pembelajaran kooperatif tipe snowball throwing pada siswa kelas VIII.B SMP Negeri 33 Makassar.

B. Lokasi, Waktu, dan Subjek Penelitian Penelitian ini dilaksanakan di SMP Negeri 33 Makassar, bulan September 2017, semester ganjil tahun ajaran 2017/2018. Subjek penelitian adalah siswa kelas VIII.B SMP Negeri 33 Makassar sebanyak 36 orang

C. Fokus Penelitian

Fokus penelitian ini yaitu model pembelajaran kooperatif tipe snowball throwing, dan hasil belajar IPS. Kedua fokus penelitian dioperasionalkan sebagai berikut: 
1. Pembelajaran kooperatif tipe snowball throwing merupakan proses pembelajaran IPS tema keunggulan lokasi dan kehidupan masyarakat Indonesia, diawali penyampaian materi dan pembentukan kelompok, setiap ketua kelompok diberi penjelasan kemudian ketua kelompok menjelaskan materi kepada anggota kelompoknya. Setiap siswa diberikan lembar kertas kerja untuk menulis satu pertanyaan kemudian dibuat seperti bola dan dilempar dari satu siswa ke siswa yang lain. Setelah mendapatkan satu bola, siswa diberi kesempatan menjawab pertanyaan, kegiatan penilaian dan penutup.

2. Hasil belajar merupakan nilai hasil tes pelajaran IPS setiap akhir siklus dengan menggunakan tes tertulis.

\section{Prosedur Penelitian}

Penelitian tindakan kelas model siklus meliputi: perencanaan, pelaksanaan tindakan, pengamatan/observasi, dan refleksi. Pelaksanaan penelitian tindakan kelas berlangsung 2 siklus dan setiap siklus sebanyak 3 kali pertemuan. Siklus I diajarkan materi keunggulan lokasi Indonesia. Pertemuan I tanggal 5 September 2017, pertemuan II tanggal 8 September 2017, dan tes tertulis tanggal 12 September 2017. Siklus II diajarkan materi pengaruh keunggulan lokasi terhadap kegiatan ekonomi, transportasi, dan komunikasi. Pertemuan I tanggal 15 September 2017, pertemuan II tanggal 19 September 2017, dan tes tertulis tanggal 22 September 2017.

yaitu:

Tahapan pelaksanaan pembelajaran

1. Menyampaikan tema yang akan dibahas.

2. Membentuk kelompok-kelompok dan memanggil setiap ketua kelompok untuk memberikan penjelasan tentang materi.

3. Setiap ketua kelompok kembali ke kelompoknya masing-masing dan menjelaskan materi yang disampaikan oleh guru kepada temannya.

4. Setiap siswa diberikan satu lembar kertas kerja untuk menulis satu pertanyaan, kemudian kertas yang berisi pertanyaan dibuat seperti bola dan dilempar dari satu siswa ke siswa yang lain sekitar 15 menit.

5. Setelah siswa dapat satu bola/satu pertanyaan diberikan kesempatan kepada siswa untuk menjawab pertanyaan yang tertulis dalam kertas berbentuk bola tersebut secara bergantian.

6. Penutup
E. Instrumen Penelitian

Instrumen yang digunakan dalam mengumpulkan data penelitian mengenai peningkatan hasil belajar IPS melalui penerapan model pembelajaran kooperatif tipe snowball throwing pada siswa kelas VIII.B SMP Negeri 33 Makassar, yaitu lembar observasi, tes, dan dokumentasi.

F. Teknik Pengumpulan Data

Pengumpulan data penelitian menggunakan observasi, tes, dan dokumentasi.

1. Observasi

Jenis data yang akan dikumpulkan melalui observasi, yaitu data mengenai proses pembelajaran IPS berdasarkan tahapan pembelajaran kooperatif tipe snowball throwing, dan data aktivitas belajar siswa mengikuti pelajaran IPS melalui pembelajaran kooperatif tipe snowball throwing di kelas VIII.B SMP Negeri 33 Makassar. Kegiatan observasi menggunakan lembar observasi berbentuk chek list.

2. Tes

Data yang dikumpulkan melalui tes adalah hasil belajar IPS siswa. Tes penelitian berisi pertanyaan tertulis yang diberikan kepada setiap siswa kelas VIII.B SMP Negeri 33 Makassar berbentuk essay. Tes setiap siklus terdiri atas 10 pertanyaan. Perhitungan perolehan nilai siswa menggunakan rumus berikut:

Nilai akhir $=\frac{\text { Jumlahyangdiperoleh skor }}{\text { Jumlah skor tertinggi }} \times 100$

3. Dokumentasi

Dokumentasi dimaksudkan memperoleh data jumlah siswa kelas VIII.B SMP Negeri 33 Makassar, dan Rencana Pelaksanaan Pembelajaran IPS kelas VIII, dan nilai KKM.

G. Teknik Analisis Data

Analisis data hasil penelitian yang diperoleh melalui observasi aktivitas mengajar guru, aktivitas belajar siswa, dan hasil tes dianalisis secara deskriptif. Pengujian hipotesis bahwa jika pembelajaran kooperatif tipe snowball throwing diterapkan dalam pembelajaran IPS, maka hasil belajar siswa kelas VIII.B SMP Negeri 33 Makassar meningkat dilakukan dengan membandingkan nilai rata-rata hasil tes antara siklus I dan II yang disesuaikan dengan pencapaian kriteria ketuntasan belajar minimal (KKM), dan didukung hasil observasi. 
Kategorisasi hasil Belajar siswa diklasifikasi 5 kategori sebagai berikut:

Tabel 1. Kategorisasi Hasil Belajar Siswa

\begin{tabular}{ccl}
\hline No. & Nilai & Kategori \\
\hline 1. & $80-100$ & Baik sekali \\
2. & $70-79$ & Baik \\
3. & $60-69$ & Cukup \\
4. & $50-59$ & Rendah \\
5. & $\leq 49$ & Sangat rendah \\
\hline
\end{tabular}

Sumber: Syah (2000:153)

Penentuan tingkat ketuntasan belajar siswa berdasarkan standar KKM 80, dengan kriteria sebagai berikut:

$<80$ dinyatakan tidak tuntas

$\geq 80$ dinyatakan tuntas

H. Indikator Keberhasilan

Indikator keberhasilan pembelajaran IPS

di kelas VIII.B SMP Negeri 33 Makassar melalui model pembelajaran kooperatif tipe snowball throwing, yaitu nilai hasil belajar siswa mengalami peningkatan pada siklus II dibandingkan siklus I, dan mencapai nilai ratarata minimal sesuai KKM 80. Demikian pula dikatakan tuntas jika 85 persen siswa memperoleh nilai hasil belajar minimal 80 dari 36 siswa kelas VIII.B SMP Negeri 33 Makassar

\section{HASIL PENELITIAN}

Hasil penelitian melalui penelitian tindakan kelas terhadap 36 siswa kelas VIII.B SMP Negeri 33 Makassar sebanyak 2 siklus, mengkaji peningkatan hasil belajar IPS melalui penerapan model pembelajaran kooperatif tipe snowball throwing pada siswa kelas VIII.B SMP Negeri 33 Makassar, disajikan dua bagian, yaitu deskripsi hasil siklus I dan II.

\section{A. Deskripsi Hasil Siklus I}

Deskripsi hasil penelitian pada siklus I mengenai pembelajaran IPS dengan model pembelajaran kooperatif tipe snowball throwing untuk meningkatkan hasil belajar IPS siswa kelas VIII.B SMP Negeri 33 Makassar, diklasifikasikan yaitu: hasil observasi aktivitas mengajar guru, aktivitas belajar siswa, hasil belajar siswa, dan refleksi.

1. Hasil Observasi Aktivitas Mengajar Guru

Hasil observasi terhadap aktivitas mengajar guru dalam pembelajaran IPS di kelas VIII.B SMP Negeri 33 Makassar melalui model pembelajaran kooperatif tipe snowball throwing menunjukkan bahwa menyampaikan materi yang akan diajarkan, yaitu keunggulan lokasi Indonesia,di mana pertemuan I disajikan materi keunggulan iklim di Indonesia, kemudian pertemuan II disajikan materi keunggulan geostrategic di Indonesia dan keunggulan tanah di Indonesia dilakukan cukup baik, karena materi dijelaskan cukup jelas, cukup detail, dan cukup sistematis. Setelah menyampaikan materi, membentuk kelompok dan memanggil masingmasing ketua kelompok untuk diberikan penjelasan materi yang dilakukan dengan baik, karena guru membentuk kelompok secara merata, yaitu 6 orang setiap kelompok (6 kelompok) dan heterogen, serta memanggil semua ketua kelompok untuk diberikan penjelasan materi. Demikian pula memberi kesempatan setiap ketua kelompok menjelaskan materi yang telah disampaikan kepada anggota kelompoknya dengan baik, karena siswa diberi kesempatan memadai untuk menjelaskan materi yang berkisar 10 menit sehingga waktu tersebut dinilai cukup memadai.

Pemberian kesempatan kepada siswa untuk menuliskan satu pertanyaan menyangkut materi yang disajikan pada setiap pertemuan dilakukan dengan baik, karena siswa diberikan waktu memadai. Demikian pula waktu saling melempar bola (kertas yang digulung) yang berisi pertanyaan, dan memberi kesempatan kepada siswa untuk menjawab pertanyaan yang dilakukan dengan baik pada pertemuan I dan II, karena memberi kesempatan kepada semua siswa untuk saling melempar bola yang berisi pertanyaan. Dalam hal pemberian kesempatan kepada siswa menjawab pertanyaan, maka hal itu dilakukan dengan cukup baik, karena guru hanya memberi kesempatan kepada sekitar seperdua dari jumlah siswa menjawab pertanyaan secara tertulis karena terbatasnya jam pertemuan, dan adanya sebagian siswa tidak aktif menjawab pertanyaan. Bahkan hanya sebagian kecil siswa aktif menyimpulkan materi pada pertemuan I, walaupun sudah sekitar seperdua dari jumlah siswa yang aktif menyimpulkan materi pada pertemuan II.

2. Hasil Observasi Aktivitas Belajar Siswa

Hasil observasi aktivitas belajar siswa dalam mengikuti pelajaran IPS materi keunggulan lokasi Indonesia melalui model pembelajaran kooperatif tipe snowball throwing di kelas VIII.B SMP Negeri 33 Makassar, yaitu sekitar seperdua dari jumlah siswa aktif menyimak penjelasan guru pada pertemuan I, dan semua siswa aktif pada pertemuan II. Hal ini berarti ada peningkatan keaktifan siswa pada pertemuan II dibandingkan pertemuan I. Bahkan semua ketua kelompok aktif menyimak penjelasan guru, semua siswa aktif 
menyimakpenjelasan ketua kelompok saat menjelaskan materi yang telah disampaikan oleh guru, dan semua siswa aktif membuat satu pertanyaan yang berkaitan dengan materi yang diajarkan yaitu keunggulan lokasi Indonesia. Selama proses pembelajaran berlangsung, hanya sekitar seperdua dari jumlah siswa aktif menjawab pertanyaan tertulis dalam kertas yang berbentuk bola. Hal ini berarti ada sebagian siswa tidak mengetahui jawaban pertanyaan yang dibuat oleh temannya. Demikian pula saat menyimpulkan materi, hanya sebagian kecil siswa aktif menyimpulkan materi pada pertemuan I, namun pertemuan II menunjukkan bahwa sekitar seperdua dari jumlah siswa telah aktif menyimpulkan materi. Hal ini dapat dilihat dari perhatian siswa saat guru menyimpukan materi keunggulan lokasi Indonesia.

\section{Hasil Belajar IPS Siswa}

Klasifisikasi hasil belajar IPS siswa kelas VIII.B SMP Negeri 33 Makassar melalui model pembelajaran kooperatif tipe snowball throwing pada siklus I, disajikan sebagai berikut:

Tabel 2. Hasil Belajar IPS Siswa Siklus I.

\begin{tabular}{clcr}
\hline Interval & $\begin{array}{l}\text { Hasil Belajar } \\
\text { Siswa }\end{array}$ & Frekuensi & Persentase \\
\hline $80-100$ & Baik sekali & 13 & 36,11 \\
$70-79$ & Baik & 18 & 50,00 \\
$60-69$ & Cukup & 5 & 13,89 \\
$50-59$ & Rendah & 0 & 0 \\
$\leq 49$ & Sangat rendah & 0 & 0 \\
\hline & J u m l a h & 36 & 100,00 \\
\hline
\end{tabular}

Sumber: Hasil Tes Siklus I

Berdasarkan tabel 2 tersebut, tampak bahwa dari 36 subjek penelitian, seperdua dari jumlah siswa atau 50,00 persen siswa memperoleh hasil belajar kategori baik, disusul kategori baik sekali sebanyak 13 siswa atau 36,11 persen, dan sisanya sebanyak 5 siswa atau 13,89 persen memperoleh hasil belajar kategori cukup. Sesuai nilai rata-rata hasil belajar IPS sebesar 77,22 dan disesuaikan dengan interval tabel 2 di atas, maka nilai rata-rata tersebut berada pada interval $70-79$ berarti baik. Jadi, hasil belajar IPS siswa kelas VIII.B SMP Negeri 33 Makassar berada pada kategori baik, tetapi ada pula sebagian siswa memperoleh hasil belajar kategori cukup mencapai 13,89 persen.

Ketuntasan belajar siswa kelas VIII.B SMP Negeri 33 Makassar berdasarkan hasil tes siklus I disajikan sebagai berikut:
Tabel 3. Ketuntasan Belajar IPS Siswa Siklus I.

\begin{tabular}{clcc}
\hline $\begin{array}{c}\text { Standar } \\
\text { KKM }\end{array}$ & Ketuntasan & Frekuensi & Persentase \\
\hline$\geq 80$ & Tuntas & 13 & 36,11 \\
$<80$ & Tidak tuntas & 23 & 63,89 \\
\hline & J u m l a h & 36 & 100,00 \\
\hline
\end{tabular}

Sumber: Hasil Tes Siklus I

Ketuntasan belajar IPS siswa kelas VIII.B SMP Negeri 33 Makassar pada siklus I hanya mencapai 36,11 persen tuntas belajarnya, sementara 63,89 persen tidak tuntas belajarnya. Hal ini berarti belum mencapai kriteria ketuntasan belajar yang ditetapkan, yaitu minimal 85 persen dari 36 siswa berdasarkan standar KKM 80. Dengan demikian, pelaksanaan penelitian harus dilanjutkan pada siklus II.

4. Refleksi

Berdasarkan hasil observasi aktivitas mengajar guru, aktivitas belajar siswa, dan hasil belajar IPS melalui model pembelajaran kooperatif tipe snowball throwing di kelas VIII.B SMP Negeri 33 Makassar, maka diperoleh hasil di samping adanya kelemahan sehingga mempengaruhi hasil belajar IPS siswa.

Hasil belajar IPS siswa rata-rata 77,22 di mana nilai rata-rata tersebut belum mencapai standar KKM 80. Bahkan masih terdapat 63,89 persen siswa belum tuntas belajarnya atau kurang dari 85 persen kriteria ketuntasan belajar secara klasikal. Hal tersebut menjadi masukan dalam melakukan telaah terhadap kelemahan selama berlangsungnya proses pembelajaran melalui model pembelajaran kooperatif tipe snowball throwing sehingga menjadi masukan dalam pelaksanaan pembelajaran IPS siklus II, yaitu:

a. Aktivitas mengajar guru pada hakikatnya telah sesuai garis besar dalam rencana pembelajaran berdasarkan tahapan pembelajaran kooperatif tipe snowball throwing, tetapi masih kurang maksimal dalam menyampaikan materi dan tahapan pembelajaran sehingga ada sebagian siswa kurang aktif menyimak penjelasan guru. Demikian pula dalam memberi kesempatan kepada siswa menjawab pertanyaan yang tertulis sehingga ada sebagian siswa tidak aktif menjawab pertanyaan temannya. Kurang melibatkan semua siswa menyimpulkan materi sehingga ada sebagian siswa kurang aktif menyimpulkan materi. Kondisi tersebut mempengaruhi penguasaan materi sehingga berdampak terhadap hasil 
belajar IPS siswa. Oleh karena itu, guru perlu menerapkan model pembelajaran kooperatif tipe snowball throwing secara lebih konsisten, lebih memotivasi secara intensif agar siswa dapat berperan lebih aktif dalam mengikuti pelajaran, terutama agar keaktifan menyimak materi, menjawab pertanyaan, dan menyimpulkan materi dapat meningkat pada siklus II.

b. Mengingatkan siswa akan manfaat kerjasama dalam belajar khususnya membahas materi pelajaran IPS, baik dari segi ilmu pengetahuan maupun sosialisasi siswa, dan mengintensifkan tanya jawab agar semua siswa dapat lebih memahami materi dalam pembelajaran IPS di kelas VIII.B SMP Negeri 33 Makassar.

\section{B. Deskripsi Hasil Siklus II}

Sebagai tindak lanjut hasil refleksi siklus I, maka dilanjutkan pelaksanaan tindakan pada siklus II dengan melakukan perbaikanperbaikan, baik dari segi perencanaan maupun pelaksanaan tindakan dengan harapan untuk meningkatkan kualitas proses pembelajaran dan hasil belajar siswa. Deskripsi hasil penelitian siklus II tentang peningkatan hasil belajar IPS melalui penerapan model pembelajaran kooperatif tipe snowball throwing pada siswa kelas VIII.B SMP Negeri 33 Makassar, diklasifikasi empat bagian, yaitu: hasil observasi aktivitas mengajar guru, aktivitas belajar siswa, hasil penilaian (hasil belajar), dan refleksi.

1. Hasil Observasi Aktivitas Mengajar Guru

Hasil observasi terhadap aktivitas mengajar guru dalam pembelajaran IPS di kelas VIII.B SMP Negeri 33 Makassar melalui penerapan model pembelajaran kooperatif tipe snowball throwing menunjukkan bahwa penyampaian materi pengaruh keunggulan lokasi terhadap kegiatan ekonomi, transportasi, dan komunikasi, serta tahapan pembelajaran pada pertemuan I dan II dilakukan secara jelas, mendetail, dan sistematis. Setelah menyampaikan materi, guru membentuk kelompok dan memanggil masing-masing ketua kelompok untuk diberikan penjelasan materi yang dilakukan dengan baik, karena membentuk kelompok secara merata, yaitu 6 orang setiap kelompok (6 kelompok dengan anggota yang berbeda dengan siklus I) dan heterogen, serta memanggil semua ketua kelompok untuk diberikan penjelasan materi. Demikian pula memberi kesempatan kepada ketua kelompok menjelaskan materi yang telah disampaikan kepada anggota kelompoknya dengan baik, karena siswa diberi kesempatan yang memadai untuk menjelaskan materi berkisar 10 menit sehingga waktu tersebut dinilai memadai.

Pemberian kesempatan kepada siswa menuliskan satu pertanyaan menyangkut materi pengaruh keunggulan lokasi terhadap kegiatan ekonomi, transportasi, dan komunikasi, disertai tanya jawab antar guru dengan siswa dan antar siswa dilakukan dengan baik, karena siswa diberi waktu memadai pada pertemuan I dan II. Demikian pula waktu saling melempar bola (kertas yang digulung) yang berisi pertanyaan, dan memberi kesempatan kepada siswa untuk menjawab pertanyaan yang dilakukan dengan baik, karena memberi kesempatan semua siswa saling melempar bola berisi pertanyaan. Dalam hal pemberian kesempatan menjawab pertanyaan, juga dilakukan dengan baik, karena memberi kesempatan semua siswa menjawab pertanyaan secara tertulis. Bahkan sekitar seperdua dari jumlah siswa aktif menyimpulkan materi pada pertemuan I, dan semua siswa aktif menyimpulkan materi pada pertemuan II, berarti ada peningkatan keaktifan siswa melalui model pembelajaran kooperatif tipe snowball throwing.

2. Hasil Observasi Aktivitas Belajar Siswa

Hasil observasi aktivitas belajar siswa dalam mengikuti pelajaran IPS dengan model pembelajaran kooperatif tipe snowball throwing di kelas VIII.B SMP Negeri 33 Makassar, menunjukkan bahwa semua siswa aktif menyimak penjelasan guru. Demikian pula semua ketua kelompok aktif menyimak penjelasan guru, semua siswa aktif menyimak penjelasan ketua kelompok saat menjelaskan materi yang telah disampaikan oleh guru, dan semua siswa aktif membuat satu pertanyaan yang berkaitan dengan materi pengaruh keunggulan lokasi terhadap kegiatan ekonomi, transportasi, dan komunikasi.

Dalam proses pembelajaran IPS di kelas VIII.B SMP Negeri 33 Makassar berkaitan dengan aspek Tanya jawab, maka dalam hal menjawab pertanyaan, semua siswa aktif menjawab pertanyaan tertulis dalam kertas yang berbentuk bola, dan saat guru menyimpulkan materi, hanya sekitar sepedua dari jumlah siswa aktif menyimpulkan materi pada pertemuan I, dan semua siswa aktif menyimpulkan materi pada pertemuan II. Hal ini berarti bahwa pada hakikatnya semua siswa telah aktif dalam proses pembelajaran IPS pada siklus II melalui model pembelajaran kooperatif tipe snowball throwing. 3. Hasil Belajar IPS Siswa 
Kategorisasi hasil belajar IPS siswa kelas VIII.B SMP Negeri 33 Makassar melalui model pembelajaran kooperatif tipe snowball throwing pada siklus II, disajikan sebagai berikut:

Tabel 4. Hasil Belajar IPS Siswa Siklus II

\begin{tabular}{clrr}
\hline Interval & $\begin{array}{l}\text { Hasil Belajar } \\
\text { Siswa }\end{array}$ & Frekuensi & Persentase \\
\hline $80-100$ & Baik sekali & 34 & 94,44 \\
$70-79$ & Baik & 2 & 5,56 \\
$60-69$ & Cukup & 0 & 0 \\
$50-59$ & Rendah & 0 & 0 \\
$\leq 49$ & Sangat rendah & 0 & 0 \\
\hline & J u m l a h & 36 & 100,00 \\
\hline
\end{tabular}

Sumber: Hasil Test Siklus II

Berdasarkan tabel 4 tersebut, tampak bahwa dari 36 subjek penelitian, sebagian besar siswa memperoleh hasil belajar kategori baik sekali mencapai 94,44 persen, dan sisanya sebanyak 2 siswa atau 5,56 persen memperoleh hasil belajar kategori baik. Sesuai nilai rata-rata hasil belajar IPS sebesar 89,72 dan disesuaikan dengan interval tabel 4 di atas, maka nilai ratarata tersebut berada pada interval $80-100$ berarti baik sekali. Jadi, hasil belajar IPS siswa kelas VIII.B SMP Negeri 33 Makassar berada pada kategori baik sekali.

Ketuntasan belajar siswa kelas VIII.B SMP Negeri 33 Makassar berdasarkan hasil tes siklus I disajikan sebagai berikut:

Tabel 5. Ketuntasan Belajar IPS pada Siklus II

\begin{tabular}{clcr}
\hline $\begin{array}{c}\text { Standar } \\
\text { KKM }\end{array}$ & Kategori & Frekuensi & Persentase \\
\hline$\geq 80$ & Tuntas & 34 & 94,44 \\
$<80$ & Tidak tuntas & 2 & 5,56 \\
\hline & J u m l a h & 36 & 100,00 \\
\hline
\end{tabular}

Sumber: Hasil Tes Siklus II

Ketuntasan belajar IPS siswa kelas VIII.B SMP Negeri 33 Makassar pada siklus II mencapai 94,44 persen tuntas belajarnya, sementara hanya 5,56 persen siswa tidak tuntas belajarnya. Hal ini berarti telah mencapai kriteria ketuntasan belajar yang ditetapkan, yaitu minimal 85 persen dari 36 siswa berdasarkan standar KKM 80. Jadi, pelaksanaan penelitian atau tindakan hanya sampai pada siklus II atau tidak berlanjut ke siklus berikutnya.

4. Refleksi

Berdasarkan hasil yang dicapai pada siklus II dalam pembelajaran IPS di kelas VIII.B SMP Negeri 33 Makassar, hasil belajar IPS siswa mencapai rata-rata 89,72 atau lebih tinggi dari standar KKM 80. Ketuntasan belajar siswa mencapai 94,44 persen atau hanya 5,56 persen siswa belum tuntas belajarnya tetapi memperoleh hasil belajar kategori baik. Demikian pula guru telah menerapkan langkahlangkah pembelajaran kooperatif tipe snowball throwing secara konsisten sesuai tahapan pembelajaran, aktivitas belajar siswa meningkat pada siklus II dibandingkan siklus I, berupa: keaktifan siswa dan ketua kelompok menyimak penjelasan guru tentang materi, keaktifan membuat pertanyaan, menjawab pertanyaan tertulis dalam kertas yang berbentuk bola, dan menyimpulkan materi pelajaran IPS pengaruh keunggulan lokasi terhadap kegiatan ekonomi, transportasi, dan komunikasi.

Berkaitan dengan hal di atas, maka hipotesis tindakan yaitu: jika model pembelajaran kooperatif tipe snowball throwing diterapkan dalam pembelajaran IPS, maka hasil belajar siswa kelas VIII.B SMP Negeri 33 Makassar meningkat, diterima. Hal ini berarti model pembelajaran kooperatif tipe snowball throwing sangat baik diterapkan untuk meningkatkan aktivitas belajar dan hasil belajar siswa pada pelajaran IPS di SMP Negeri 33 Makassar.

Model pembelajaran kooperatif tipe snowball throwing dapat meningkatkan hasil belajar siswa kelas VIII.B SMP Negeri 33 Makassar. Selain itu, penerapan model pembelajaran kooperatif tipe snowball throwing juga dapat meningkatkan keaktifan siswa mengikuti pelajaran IPS melalui kegiatan kerjasama dalam kelompok, khususnya dalam membuat pertanyaan dan menjawab pertanyaan. Hal ini relevan dengan pendapat Isjoni (2010: 13) bahwa model pembelajaran kooperatif dapat membantu siswa memahami konsep yang sulit, menumbuhkan kemampuan berpikir kritis, bekerja sama, dan membantu teman. Demikian pula siswa terlibat aktif dalam pembelajaran sehingga memberikan dampak positif terhadap kualitas interaksi dan komunikasi yang berkualitas, dapat memotivasi siswa untuk meningkatkan hasil belajarnya.

Hasil penelitian dan pendapat di atas menunjukkan aktivitas belajar dan hasil belajar yang dicapai siswa dapat meningkat melalui pemilihan dan penerapan model pembelajaran yang tepat sesuai tuntutan materi pelajaran IPS, yaitu pembelajaran kooperatif tipe snowball throwing yang menuntut kerjasama antara siswa secara kelompok dalam melakukan kegiatan belajar dalam membuat dan menjawab pertanyaan. Melalui pembelajaran kooperatif tipe snowball throwing, siswa dapat lebih termotivasi atau saling memotivasi, dapat bekerjasama atau saling membantu dalam belajar IPS sehingga penguasaan terhadap materi 
pelajaran IPS dapat lebih maksimal dan meningkatkan hasil belajarnya.

\section{SIMPULAN DAN SARAN Simpulan}

Hasil penelitian mengenai peningkatan hasil belajar IPS melalui penerapan model pembelajaran kooperatif tipe snowball throwing pada siswa kelas VIII.B SMP Negeri 33 Makassar, disimpulkan bahwa hasil belajar IPS dapat meningkat melalui penerapan model pembelajaran kooperatif tipe snowball throwing, tema keunggulan lokasi dan kehidupan masyarakat Indonesia. Siklus I, hasil belajar IPS termasuk kategori baik (rata-rata 77,22) tetapi belum mencapai kriteria ketuntasan belajar yang ditetapkan karena tuntas belajarnya hanya 36,11 persen, kemudian siklus II berada pada kategori baik sekali (rata-rata 89,72) dan telah mencapai kriteria ketuntasan belajar yang ditetapkan karena tuntas belajar mencapai 94,44 persen atau berada di atas batas minimal 85 persen ketuntasan belajar secara klasikal. Terjadinya peningkatan hasil belajar IPS melalui penerapan model pembelajaran kooperatif tipe snowball throwing didukung peningkatan aktivitas belajar siswa, berupa: keaktifan siswa dan ketua kelompok menyimak penjelasan guru berkaitan dengan tema keunggulan lokasi dan kehidupan masyarakat Indonesia, membuat pertanyaan, menjawab pertanyaan tertulis dalam kertas yang berbentuk bola, dan menyimpulkan materi pelajaran IPS tema keunggulan lokasi dan kehidupan masyarakat Indonesia.

\section{Saran}

Sehubungan dengan simpulan di atas, maka disarankan sebagai berikut:

1. Guru pelajaran IPS sebaiknya dalam mengajarkan materi agar berupaya lebih mengedepankan partisipasi belajar siswa secara kelompok, seperti pembelajaran kooperatif tipe snowball throwing karena terbukti dapat meningkatkan hasil belajar siswa. Dalam pelaksanaan pembelajaran melalui pembelajaran kooperatif tipe snowball throwing, guru sebaiknya melakukan pengawasan dan bimbingan agar dapat meningkatkan kerjasama dan motivasi siswa dalam belajar sehingga dapat meningkatkan aktivitas belajar dan hasil belajar siswa.

2. Siswa sebaiknya selalu aktif mengikuti pelajaran melalui model pembelajaran yang diterapkan oleh guru agar pemahaman terhadap materi pelajaran IPS lebih maksimal dan mendukung peningkatan hasil belajar.

\section{DAFTAR RUJUKAN}

Abdurrahman, Mulyono. 1999. Pendidikan Bagi Anak Berkesulitan Belajar. Jakarta: Rineka Cipta.

Abimanyu, Soli., Daruma, A. R., dan La Sulo, S. L. 2005. Psikologi Pendidikan. Makassar: FIP UNM.

Anita. 2007. Cooperative Learning. Jakarta: Grasindo.

Arikunto, Suhrasimi, Suhardjono, dan Supardi. 2012. Penelitian Tindakan Kelas. Jakarta: Bumi Aksara.

Asma, N. 2006. Model Pembelajaran Kooperatif. Jakarta: Depdiknas.

Disman, Epon Ningrum, Arie Sujito, dan Ari Sapto. 2014. Ilmu Pengetahuan Sosial. SMP/MTs Kelas VIII, Semester I. Jakarta: Kemendikbud Republik Indonesia.

Djamarah, Syaiful Bahri, dan Zain, Azwan. 2002. Strategi Belajar Mengajar. Jakarta: Rineka Cipta.

Gintings, Abdorrakhman. 2008. Esensi Praktis Belajar dan Pembelajaran. Bandung: Humaniora.

Hamalik, Oemar. 2003. Kurikulum dan Pembelajaran. Jakarta: Bumi Aksara.

Isjoni. 2010. Cooperative Learning. Efektivitas Pembelajaran Kelompok. Bandung: Alfabeta.

Karli, H. dan Yuliariatiningsih, M. S. 2002. Implementasi Kurikulum Berbasis Kompetensi, $\quad$ Metode-Metode Pembelajaran. Jakarta: Bina Media Informasi.

Lie, A. 1999. Metode Pembelajaan Gotong Royong. Surabaya: Citra Media.

Purwanto. M. N. 2007. Psikologi Pendidikan. Bandung: Remaja Rosdakarya.

Sanjaya, Wina. 2006. Strategi Pembelajaran Berorientasi Standar Proses Pendidikan. Jakarta: Kencana Prenada Media.

Sardiman, A.M. 2001. Interaksi dan Motivasi Belajar Mengajar. Jakarta: Raja Grafindo Persada.

Slameto. 2003. Belajar dan Faktor-faktor yang Mempengaruhinya. Jakarta: Rineka Cipta.

Suprijono, Agus. 2010. Cooperative Learning, Teori dan Aplikasi Paikem. Yogyakarta: Pustaka Pelajar. 
Syah, Muhibbin. 2000. Psikologi Pendidikan dengan Pendekatan Baru. Bandung: Remaja Rosdakarya.

Thabrany, Hasbullah. 2003. Rahasia Sukses Belajar. Jakarta: Raja Grafindo Persada.

Undang-Undang Republik Indonesia Nomor 20 Tahun 2003 tentang Sistem Pendidikan Nasional Beserta Penjelasannya. Bandung: Nuansa Aulia.

Winkel. 1996. Prinsip-prinsip Pengelolaan Sumber Belajar. Bandung: Remaja Rosdakarya. 